\title{
The Necessity of Engaging with Politics: Lessons from the Grass Roots in South India
}

\author{
Sunita Abraham
}

\begin{abstract}
This article highlights the growing role, relevance and practice of politics in the everyday lives of poor people and grass roots NGOs, in relation to rural local government. It draws on experiences from a case study gram panchayat (lowest tier of local government) in the south Indian state of Karnataka. The analysis focuses on the period 1994-2006. The article describes how poor people who engage actively in different aspects of political participation are better able to influence the functioning of local government and the disbursal of material benefits from it. In doing so, it argues that this engagement is becoming more of a necessity for poor people. Even those who are reluctant find that political participation enables them to voice their demands and challenge dominant interests more advantageously.
\end{abstract}

\section{Introduction}

In rural India, politics is often considered to be largely the preserve of politicians and their affiliates. With the devolution of powers to local government (constitutional amendment passed in 1992) ${ }^{1}$ and the conduct of regular elections this perception is gradually changing. Reservations for historically marginalised groups like the Scheduled Castes (SCs), Scheduled Tribes (STs) ${ }^{2}$ and women have also broadened their opportunities for political participation. Increasingly, poor people are harnessing the potential of devolution by participating in various forms of political action (Alsop, Krishna and Sjoblom 2001; Bardhan, Mitra, Mookherjee and Sarkar 2009). Democratic decentralisation is also providing $\mathrm{NGOs}^{3}$ at the grass roots with an opportunity to play a more explicit role in matters relating to politics and local government (Chhotray 2008).

This article unpacks the relationship of poor people and a grass roots $\mathrm{NGO}^{4}$ with rural local government. It describes the growing engagement of vulnerable and marginalised people with politics in this context, and explains how greater political participation allows for more influence over the functioning of local government and the disbursal of material benefits from it. In doing so, it highlights that even those who are not keen or interested in such involvement now find that this engagement is becoming a necessity. The article draws on material from my doctoral thesis which was a comparative study of the interface of gram panchayats, grass roots NGOs and poor people in two south Indian states. It takes an in-depth look at the political dynamics and outcomes within one of the gram panchayats in the south Indian state of Karnataka.

There is growing evidence that understanding the role and importance of politics is central to improving the lives of poor people (Green 2008; DFID 2010). In these studies, politics is not examined through a rational-actor lens (where actors pursue strategic self-interest), but is studied by employing a more substantive approach which examines prevailing socioeconomic relations and underlying structural conditions. Using this approach is important while studying events at the local level as research suggests that the impact of local-level politics on democracy and development needs to be critically analysed, for it has the potential to both curtail and foster substantive change (Harriss, Stokke and Törnquist 2004).

In this article, I have used the term politics in three different senses. Firstly, I have used it in reference to institutional electoral practices. The 
two other senses in which I have used it relate to the additional ways in which gram panchayat-level informants interpreted these terms. In the more limited sense, it refers to competition between cliques. In the more substantive sense, it refers to the interplay of interests and forces that seek to control authority in village society in order to gain influence or retain command over decisionmaking, resources and benefits. ${ }^{5}$ The account of Donnapalli gram panchayat describes and explains how politics at the grass roots has moved beyond institutional electoral practices to include a gradual reconfiguration of traditional hierarchies - in ways that allow poor people to have access and influence over decision-making and the distribution of resources and benefits.

The article has four sections. Section 2 provides information about the research context in Karnataka, methods and mode of analysis, together with reflections on the research process. Section 3 describes the research setting at the district and lower levels of government, unpacks the experiences in Donnapalli gram panchayat, and discusses the findings. Finally, the conclusion highlights the key lessons.

\section{Background and details of the research 2.1 The context in Karnataka}

Like many other societies in the world, rural society in India has been intertwined with the practice of politics - both in its institutional and substantive forms. In much of southern India, political power was traditionally concentrated in the hands of the village 'headman' who belonged to either an upper caste ${ }^{6}$ or a dominant caste, ${ }^{7}$ and also in a more limited sense with leaders from other caste/tribe and religious groupings (Mandlebaum 1970). Post-independence, the authority and influence (especially over panchayats) of the headman and other leaders is gradually eroding (Robinson 1988; Krishna 2007). This has in part been aided by the development and expansion of democratic institutions and practices. The constitutional amendment in 1992 which gave states the responsibility to devolve powers to local government has further extended opportunities for vulnerable and marginalised people to take up leadership positions and influence the functioning of panchayats (Kudva 2006).

However, attempts at decentralisation have varied across the Indian states as their governments are free to determine the design, scope and extent of devolution of resources and power - provided they adhere to a set of uniform requirements. During the period of my study (1994-2006), ${ }^{8}$ the south Indian state of Karnataka has made more efforts than many other states to strengthen local government (Mathew and Buch 2000). Both parties that headed governments during this term (the Congress and Janata Dal (Secular) [JD(S)]) have adopted a liberal, hands-off approach to panchayats; and have devolved a measure of funds and powers to them (Meenakshisundaram 2005). They have also been broadly supportive of NGO involvement in panchayat-related matters (Hansen 1999).

Although Karnataka scores over many other states in terms of political and administrative devolution; in terms of finances (until the 2003 amendments), and government officials' accountability to these institutions, its efforts have been inadequate. However, the change in financial allocations in 2003 has meant that Karnataka's gram panchayats now receive about 50 per cent of the total transfers compared to the two upper tiers.

\subsection{Research methods and reflections \\ 2.2.1 Methodology and assessment}

In order to evaluate the experiences of poor people in Donnapalli gram panchayat, I use both qualitative and quantitative data. The qualitative data is drawn from semi-structured interviews and participant observation, and provides an understanding of the context and changing dynamics. The quantitative data compares responses of survey respondents (20 poor people) ${ }^{9}$ across 20 key questions. The experiences are assessed by focusing on the level of political participation and material benefits attained at a specific time during 2005-06.

The first dimension is evaluated by examining achievements with respect to (1) the awareness of poor people in relation to different aspects of panchayat-related political participation, (2) the physical practices associated with this political participation (voting, contacting elected representatives, petitioning and protesting), and (3) the effectiveness of this political participation - assessing whether the active utilisation of voice has helped to shape the dynamics within the panchayat or the decisions and practices of individuals (citizens, elected functionaries, leaders and officials) and groups. In other words, I assess the awareness, voice and influence of poor people. 
The second dimension relates to the acquisition of panchayat-related material benefits - both individual and community. I primarily examine benefits that are provided by the lowest tier of panchayats. Individual benefits include houses, pensions and daily-wage labour on various employment projects. Collective benefits include the provision of roads, potable water facilities and street lights.

Aside from collecting data at the gram panchayat level, I also conducted interviews with key informants at the intermediate panchayat, district panchayat and state level. In addition, I analysed information available online and in print media. Data from these different avenues helped to provide a detailed and balanced picture of the dynamics and outcomes at the grass roots.

In the next sub-section, I reflect on my experiences while conducting fieldwork and analysing data. I have discussed these experiences in some length as part of the aim of this IDS Bulletin is to shed light on the experiences of doctoral students while conducting research and highlight the ways in which they have dealt with various methodological issues and challenges. These reflections also help to situate the findings in Section 3.

\subsubsection{Reflections on fieldwork and data analysis}

During my time in the habitations, I lived in the houses of poor people (mainly members of NGOaffiliated village groups). It was important to situate myself in the village, not only to get a more authentic flavour of the everyday experiences of citizens but also for reasons relating to data collection. Poor people (invariably, daily-wage labourers) would be out at work during the day, and political leaders would be accessible mostly in the late evenings and early mornings. On the whole, people were very welcoming. They were interested to know why I was doing the study and what my background was. Interviewees (especially poor people) would often ask me what I was going to achieve by conducting this research, why I would want to stay in a poor person's house, and how they would benefit from my findings. At the start of my stay, some respondents were unsure about my research, but staying in the village and having local contacts helped to dispel most doubts.

I speak the local language Telugu, ${ }^{10}$ which was useful to conduct interviews and interpret discussions. In general, there was generous cooperation from the interviewees, but there were some instances when people were suspicious about participating or unsure about responding. For example in the gram panchayat under study, a few of the senior political leaders from the main village were unsure of my claim of being a researcher as they suspected that I was an investigative journalist. Some respondents gave politically correct answers, or underreported, or made inflated claims. A few of the respondents, like well-known political leaders or senior NGO staff, were seasoned interviewees. In order to get reliable data, I had to be careful about how I worded my questions and steered the course of the interview. I also had to factor in the positionality of interviewees themselves. So, to reduce biases, I informally ascertained the political leanings and reliability of potential interviewees (wherever possible). To minimise 'recall'-related biases, I provided a point of reference or memory-aid by mentioning a significant event or individual from the particular period or year.

Government staff and elected functionaries at the gram panchayat level were often reticent about sharing minutes, audit reports, baseline data, muster rolls and financial information in relation to panchayats. For instance, the Donnapalli panchayat secretary (government-appointed administrative staff) was very reluctant to share financial reports and minutes from the gram panchayat meetings. He kept saying that the files were not available as they were with the auditors. ${ }^{11}$ I was finally able to examine these files after senior political leaders from within the panchayat put pressure on him to produce the files.

In many cases, the problem of paucity of information was compounded by the fact that the available material was outdated, missing, lost, inaccurate, doctored, inconsistent, insufficient or incomplete. So, I was cautious in my use of secondary sources of information. These limitations reinforced the importance of conducting semi-structured interviews. Similarly, obtaining secondary sources of information from the NGO under study had to be carefully negotiated, and was often contingent on the quality of my personal rapport with senior staff.

During fieldwork, I was aware that my own positionality of being a young, urban, middle-class, 
educated, married Indian woman, who was researching politically sensitive issues, would affect the research process. At the same time, being an urban woman student had its advantages at the habitation level, in that it afforded greater private access to other women while also allowing fairly open access to interviews with men.

While analysing data and writing up findings, I was mindful that my own values, preconceptions, and assumptions could influence the findings of the research. In particular, my interpretation of data relating to people's perception on issues relating to poverty, politics and change would be affected by my own 'theoretical, political and personal concerns' (Booth, Leach and Tierney 2006: 3). These concerns had the potential to both enrich and bias findings, and so it was often hard to strike the right balance.

One of the key findings that this research process was able to highlight was the growing role of politics in the everyday lives of poor people. In the next section, I describe how politics plays a critical role in their lives in relation to participating in panchayat-related activities and accessing material benefits.

\section{Unpacking experiences in Donnapalli gram panchayat}

\subsection{Background - Chikballapur district and NGO} Akravati

This article focuses on a gram panchayat located in Chikballapur district. ${ }^{12}$ This district is interior, backward, semi-arid and drought-prone with a high dependence on well (open and bore) irrigation. There are no major rivers, reservoirs or canals within the districts. The economy is primarily agrarian and the dominant mode is rain-fed agriculture. Within village society, the traditionally powerful community are the Vokkaligas - a dominant caste. They are a peasant farming caste that belongs to the Shudra varna (category). However, since families within these caste groupings are often landed and have significant traditional influence in the village, they have a higher status compared to other castes that fall within the Shudra bracket.

Chikballapur has many small NGOs that work on a variety of rural development issues but some are short-lived and run by unscrupulous operators or are financed by local political leaders who view them as a way to amass funds from donors. Most of the 'credible' NGOs work on service delivery issues. This article examines the role of a large, long-established NGO called NGO Akravati ${ }^{13}$ that works with poor people in rural areas through the multi-pronged approach of conscientisation, mobilisation and service delivery. It has been working on issues relating to panchayats from the late 1980s. NGO Akravati works in about 900 habitations covering four different legislative constituencies (linked to the state government's Lower House of directly elected representatives). The NGO is a formal (with salaried employees), mainly donor-funded (international) collective. It operates through a sangha (membership-based village group facilitated by the NGO) which is a federation and a separate legal entity. The sangha is largely made up of daily-wage labour families, many of whom are from the Scheduled Castes and Scheduled Tribes. There is a close link between the NGO and the sangha as more than half of the NGO staff are drawn from it. With respect to local government, NGO Akravati has disseminated information, mobilised sangha members to contest seats and make demands on the panchayats, and provided training on related issues.

The political contest in this district is mainly between the Communist Party of India (Marxist) $[\mathrm{CPI}(\mathrm{M})]^{14}$ and the Congress party. All tiers of elections display a high degree of political competition with increasingly narrow margins of victory. Aside from the three-tiered panchayats, the district is carved into five different legislative constituencies. Each member or MLA (Member of Legislative Assembly) is associated with a single-member legislative constituency at the sub-district level and is elected for a period of five years. MLAs command significant influence over the local bureaucracy as they have powers to orchestrate transfers of government officials within their constituency, especially the Executive Officer (EO) - the senior-most official of the taluk panchayat (the intermediate tier), and gram panchayat secretaries.

\subsection{Maddilpalli Legislative Constituency}

Donnapalli, the gram panchayat under study, is located in Maddilpalli legislative constituency. Here, the same CPM leader (male, Vokkaliga) was an MLA in both the 1994 and 2004 term whereas the independent (affiliated to the Congress party) candidate (male, Baljiga) ${ }^{15}$ was an MLA in 1999. Aside from differing political party affiliations, the difference in caste between the 
two main contestants has contributed to a degree of caste polarisation in assembly elections. In addition, whereas the CPM leader's term is normally associated with a heightened degree of tension in the villages, brow-beating of the bureaucracy and clear party favouritism in awarding 'contracts' and benefits; the Congress affiliated candidate's (referred to as a rebel-Congress candidate locally ${ }^{16}$ term is considered to be more relaxed, non-intrusive and accommodative. In part, this is because the latter's support base is partially made up of sangha members associated with NGO Akravati. So, when he is in power, the senior leaders of the sangha together with the senior management of the NGO are able to exert some amount of pressure on him to ensure that their members benefit from panchayats and that there is no wilful obstruction on his part. ${ }^{17}$

However, this open support to the rebel-Congress candidate has driven a wedge between the CPM MLA and the sangha supporters.

During the study period, the political party-inpower in the taluk panchayat in Maddilpalli has often been at odds with the ruling MLA. This 'opposition' has ensured that no party is able to completely dominate the political scene, and spoils and benefits are distributed to supporters across the divide. However, this has not always translated into positive gains for marginalised and vulnerable people. Although both the MLA and the intermediate panchayat members have tried to channel benefits to their vote bases, they have often been thwarted by intra-party politics and local village dynamics. In addition, the rotation of reservations for the post of chairpersons in taluk panchayats (every 20 months within a five-year term) has increased opportunities for defections, generating further instability in planning and implementing panchayat policies.

\subsection{The growing relationship with politics (1994-2006)}

Donnapalli is a remote gram panchayat that covers 12 habitations and 1,260 households. NGO

Akravati has been operating here since the early 1990s on a range of issues relating to rural development and democratisation. It works with small and poor peasant families in seven out of the 12 habitations, through the medium of sanghas.

This gram panchayat is the seat of a large landowning, dominant caste (Vokkaliga) family. It also has a sizeable concentration of Scheduled Caste and Schedule Tribe households. In the past, most of these families were under the control of the big landowning family. NGO Akravati found it particularly hard to build a sangha in the main village where the most powerful members of the family live. Furthermore, it is located in a CPM stronghold, which has helped to ensure that intermediate and district panchayat members across all three terms ${ }^{18}$ were almost all CPM supporters. Despite this, at the gram panchayat level, there has been some support for the Congress as a section of the big family supports this political party.

The family had de facto control over the panchayat till the middle of the 2000 electoral term. They ensured that gram panchayat meetings and gram sabhas (village assemblies) were a sham, and they successfully curtailed the dispersion of material benefits to most poor people. Although members within this powerful family had different political party affiliations, the covert understanding was that power should remain within the family. So, in the 1994 gram panchayat term, when the reservation category ${ }^{19}$ for the post of president was allotted to the SCs, an illiterate lady from this community was installed as the president. However, the family faced more resistance in the next term.

In the first 30 months of the 2000 term, ${ }^{20}$ a male Scheduled Caste member was elected ${ }^{21}$ as president. In the intervening period, the gram panchayat had witnessed the rise of many smalltime leaders and political aspirants. The big family was increasingly aware of the threat that these new leaders (some of whom were from marginalised castes, like the new Scheduled Caste president) posed to their traditional authority, and the difficulties of co-opting the more vociferous aspirants. This defiance had been evident in the more intense contestation for panchayat council (referred to locally as ward member) seats between the two main political parties in the gram panchayat elections of 2000 . In the 1994 elections, there were few contests and more unanimous nominations:

There was more interest in panchayat elections in the 2000 term. Contestants felt that being a ward member gave them access to material benefits and a chance to be a leader. And as for the voters, even people who would not normally vote felt that they could use their vote to bargain for some panchayat benefits. (Elected male member, pers. comm. 2006) (2 $^{22}$ 
At the start of the next 30 months, when the category was announced as general (open to all communities), a young educated dominant caste $\operatorname{man}^{23}$ was chosen as the new president. Unlike presidents of the past, this candidate was unwilling to toe the line, and gradually began to strike out on his own. He tried to build a base around the backward castes (part of the Shudra varna), and also channelled community and individual material benefits from the gram panchayat to the poorer families (across the castedivide), including sangha households. Although he lacked support from the intermediate and district panchayat members (CPM supporters), the Congress-affiliated president was able to accumulate a sizeable amount of additional material resources for the gram panchayat from the Congress-affiliated MLA.

The dominant caste leader from the main village was highly displeased with this insubordination and tried to engineer a no-confidence motion against him by bribing Congress-affiliated ward members to defect to the opposition CPM, and influencing the CPM-affiliated panchayat secretary (government official attached to the panchayat). The leader also received tacit support from the ex-MLA, who belonged to the CPM. At this stage, the young president turned for support to his new base amongst the backward castes and sangha members. In response, the sangha functionaries at the gram panchayat and taluk level, with the backing of the NGO, the ruling Congress-affiliated MLA and taluk-level Congress leaders; called for a major strike on the day of the no-confidence motion.

On the day... about 2000 people from across the taluk came for a strike and prevented the opposition ward members from entering the gram panchayat office. Most of these people who came for the strike belonged to the sangha. (Elected male member, pers. comm. 2006) ${ }^{24}$

It was this show of strength that changed the tide in favour of the sangha. By the time of the next gram panchayat elections in 2005, the sangha had expanded membership within Donnapalli.

Five years ago in the 2000 elections we realised that coverage of sangha members was less in the villages of the panchayat. So, in the last elections [2005] we made alliances with the neutral population and encouraged them to join the sangha and that is how we managed to win the necessary votes and get so many elected members this time. Also the rich, higher caste people like S__ Reddy are seeking alliances with us because of the strength of the group. This has positive benefits for us. (Sangha functionary, pers. comm. 2006) ${ }^{25}$

Some of the poor people, who had been reluctant or indifferent to any engagement with panchayats, now saw the value and results of involvement and collective mobilisation. They could see that it could challenge the dominance of traditional elites. More importantly, they felt that in order to secure material benefits and influence over the panchayats they needed to participate in political actions:

We need politics for development. There is a difference between asking someone else and getting things ourselves. For so long, we have had to approach B___ (dominant caste leader) for anything related to panchayats. So we joined the sangha because we thought that as a group we could bargain better and have more control over the running of the panchayat. We don't really want to get involved in politics but we have to because all of the decisions are being made on the basis of political party affiliations. Also, the gram panchayat is getting more funds, so poor families like us need to be able to influence its functioning if we want to get access to benefits. (Key informant, pers. comm. 2006) ${ }^{26}$

After the 2005 panchayat election, the sangha functionaries negotiated with the ward members, and local leaders (Congress supporters) to ensure that their sangha member, an illiterate female from the Shudra varna was elected as president. She has been able to channel benefits to poorer families, especially within the sangha; but has had to balance that with appeasing powerful Congress supporters within the panchayat. Placating these local leaders has become trickier with the increase in financial allocations to the gram panchayats, as they are eager to cash in on contracts. Although sangha members are trying to ensure that the new president remains accountable to them, there is already evidence that cracks are developing in this relationship.

The above description of the dynamics in Donnapalli panchayat highlights the growing role, 
relevance and practice of politics in the lives of poor people. Aside from voting and having a general awareness about panchayats, they are also campaigning in elections, voicing demands, mobilising in groups and taking part in confrontational action. This is borne out in the survey findings too. Most respondents are aware about the basic role and functions of panchayats and have made some demands. Those that are members of the sangha have shown more interest than others in participating in campaigning, mobilising and protests. Individual demands for daily-wage labour, houses and pensions have not always been met, but they have had more success with the provision of collective benefits like potable water and roads. In addition, the qualitative data indicate that sangha mobilisation has made a difference in terms of members gaining priority in the distribution of individual benefits. Their petitions and campaigns have also helped to secure the provision of collective benefits like potable drinking water.

The account of Donnapalli also brings out the NGO's role in building the political capabilities of sangha members. NGO Akravati has been able to mobilise them to make demands, participate in protests and strikes, contest elections, and capture a sizeable share of the seats so that they can influence decision-making within the gram panchayat. In order to do that it has disseminated relevant information, trained sangha functionaries, and networked with various political leaders and government officials. Thus, working on panchayatrelated issues has necessitated greater involvement in political matters. At times, this has led to confrontations with various leaders and groups whose interests have been affected by the growing awareness and strength of sangha members and their supporters. The NGO has dealt with any threats of violence and reprisal by drawing on the support of sangha members, lawyers, and officials and politicians at higher levels of government.

At the village level in Donnapalli, sangha members have had to balance considerations of employment and family, while voicing demands and participating in confrontational action. In some cases, village-level leaders affiliated to the CPM have tried to co-opt sangha functionaries or intimidate their families. NGO staff feel that this tension and antagonism is part of the process of redefining traditional boundaries and bringing about change:
Sangha functionaries and members have to reconfigure existing power relationships at the grass roots themselves. This is a slow process and it can have many setbacks. We can provide support from the outside through training, campaigns and legal aid but the battle is primarily theirs. (NGO head, pers. comm. 2005) ${ }^{27}$

In the next sub-section, I elaborate on these viewpoints and findings, and highlight the links between politics and poor people in relation to local government institutions.

\subsection{Discussing and situating findings}

Over the study period, the augmentation of powers and funds to panchayats has helped to usher in greater political competition and incremental social change in Donnapalli. Although the main dominant caste family still wields some power on the social and economic fronts, their command over local politics has suffered a serious blow. Earlier, they dictated the terms but now control has shifted to a wider group. The leader from the family has to bargain and compete with sangha and other political party leaders from traditional lower castes in order to influence decision-making within the gram panchayat:

After this system of elections, things have changed completely. Now people don't listen to $\mathrm{B} \_$_. Now there is no unity in village. In the past there was just one leader. For justice they might still come to me for a decision, or rather a group of us. But we don't have much say as far as politics is concerned. (Key informant, pers. comm. 2006) $)^{28}$

This rise in political competition and the representation of leadership from non-traditional groups at the grass roots has also been documented in recent scholarship. Chandrashekhar (2009) and Mullen (2011) draw on village-level data to highlight the role of political competition in the context of democratic decentralisation, and Alm (2010) draws attention to the emergence of leaders from non-traditional backgrounds.

Although there continues to be much scholarship about the capture of local institutions by traditional elites (see for instance Dutta 2012; Palaniswamy and Krishnan 2012), there is evidence that democratic decentralisation is gradually helping to allow for a fairer 
distribution of panchayat-related benefits (Daftary 2010). This article builds on Daftary's research in Gujarat to highlight the growing role of leaders within panchayat settings who come from non-traditional groups. In Donnapalli, some leaders from marginalised communities are financially better-off than others from within their group, but in other cases these emerging leaders are from poor backgrounds and are associated with the sangha. Those from the latter group are forming new political identities although they are not members of any political party, they strategically choose to affiliate themselves with a particular party in order to gain resources and influence the functioning of panchayats. Thus, as Cornwall, Robins and Von Lieres suggest, new forms of public engagement in democratic arenas are helping to create new political identities (2011: 8-9).

Leaders from the sangha utilise its collective strength to bargain for material benefits, participate in social and electoral campaigns, and increasingly to secure election victories. This strength has also enabled candidates from the sangha who are standing for panchayat elections to spend less on elections compared to their competitors. However, as the article illustrates, once they are in positions of power their accountability to the sangha is more fluid and this has potential knock-on effects on the cohesiveness of the sangha. As the amount of funds available for the use of gram panchayats increases there are greater possibilities of rifts appearing between sangha members and leaders..$^{29}$ In addition, the experience of Donnapalli from 2003 onwards suggests that larger financial allocations to the lowest tier attract small-time leaders who are eager to make money on contracts for implementing works.

A rise in the number of local leaders, the associated level of political competition, and the devolution of funds has also meant that some of these leaders and elected panchayat functionaries are more readily switching party affiliations in order to further their ends. This fluidity in political identities is on the rise and is connected to the augmentation of resources and powers within government institutions, especially at the lowest tier. Other emerging leaders at the grass roots have built on existing political party affiliations and acquired skills as political entrepreneurs in order to boost their chances of being re-elected or furthering their political careers. The young gram panchayat president from the 2003 term and the lady president from the 2005 term have developed alliances with politicians and government officials at higher tiers of government and used these to bargain and acquire material benefits for their supporters. They have also maintained and built their links with local leaders and the sangha by awarding contracts and providing information and assistance.

This entrepreneurship has also been exhibited by leaders from within the sangha. By formulating electoral alliances and brokering votes for development, sangha leaders from vulnerable and marginalised backgrounds have learnt how to use statutory provisions and electoral strategies to alter the balance of power and acquire benefits for their members. These changes in the nature of local leadership and political competition build on the recent work of Manor (2010) who has documented the emergence of small-time political entrepreneurs and the fluidity of political identities in India.

\section{In Donnapalli panchayat, these changes reflect} the growing relevance of politics in the everyday lives of its people. As mentioned in the introductory section of this article, I have used the word politics in three different senses firstly in relation to institutional electoral practices, secondly in terms of competition between cliques, and thirdly as the interplay of interests and forces that seek to control authority in village society. The Donnapalli account highlights that all three associations with the term are gaining importance. Firstly, over the period under study, the regular conduct of elections, and the incremental devolution of powers and resources have meant that there is better awareness about various forms of institutional electoral practices and greater participation in related physical practices. Secondly, the discussion relating to political competition highlights the growing rivalry amongst groups within the panchayat particularly between the sangha and CPM supporters. Thirdly, the strategies and collective power of the sangha have made it a force to reckon with, and have helped members to increase participation in institutional electoral practices and forge alliances in order to gradually alter the power equations and 
distributional outcomes within the panchayat. In doing this, they have been able to highlight the role that substantive politics can play in improving the lives of poor people.

Sangha members, most of whom are poor and from the Scheduled Castes, have realised that harnessing the economic potential of panchayats requires a deeper engagement with politics - not just as individuals but more importantly as a group. Although they have had limited success in terms of securing individual benefits, their protests and petitions have led to the provision of certain collective material benefits. As one of the sangha functionaries explains:

The reason why we decided to have politics as an integral part of the sangha was to get benefits from government without having to bend over backwards begging someone to get benefits for us. Panchayats and sanghas are both needed... Sanghas give us identity and collective power... [but] some things sanghas cannnot give us like hostel seats, houses, water supply, and street lights. (Sangha functionary, pers. comm. 2006) ${ }^{30}$

The advantages of engaging in collective processes with respect to local government institutions have also been brought out in Sharma and Sudarshan's study of women's groups in north India (2010). They argue that such processes provide opportunities for women's groups to build networks across villages, support each other in times of conflict and confrontation, and reinforce norms of equality and inclusiveness through debate and negotiation. The ability of these traditionally marginalised groups to participate more effectively in panchayats through collective efforts is similar to the sangha's capacity to influence the functioning of panchayats through various forms of political participation (e.g. voting, contacting elected representatives, campaigning, petitioning and carrying out strikes). This participation of sangha members is both necessary and useful. Priyadarshee and Hossain (2010) argue that in order to make the functioning of panchayats more relevant to the deprived population it is important to find ways to enhance the participation of poor people.

The sangha has also recognised that more substantive political participation in panchayats requires going beyond gaining awareness and exercising voice to actually influencing the functioning of the panchayat. As a group, the sangha have attempted to do that by capturing a majority of the seats in the council. They have tried to expand membership within the panchayat, and form alliances with groups and leaders from different castes and economic backgrounds. However, these alliances have made it difficult for the panchayat president in the 2005 term (who is a sangha member) to make unbiased decisions about the distribution of material benefits as she has to conciliate local leaders who wish to make money on contracts.

On the other hand, the alliances have helped sangha members win positions as ward members, and reduced election costs for contestants from within the sangha when compared to those who are associated with a political party. This has made it more possible for sangha members from poorer backgrounds to stand for elections. There has been a steady increase in spending by candidates over the period under study, and the costs are making it increasingly prohibitive for poor people to contest in panchayat elections. Recent reports highlight that election spending by candidates has increased dramatically in parallel with the quantum of funds that are now being made available to the lowest tier (see Bhatt 2012).

At the same time, the intense competition for ward member seats has led to more political tension and divisions within the panchayat. This has had knock-on effects on the sangha too. It has made it easier for local political leaders from the CPM to co-opt some of its leaders and exploit existing divisions within the group. However, sangha functionaries feel that this process of weeding out weak leaders and individuals plays an important part in securing the unity of the group in the long run. These links between the sangha and panchayats bring out the growing relevance of politics in the everyday lives of poor people. While this association has helped them secure a degree of material benefits from local government bodies, it is also creating new tensions within the sangha, which in turn can damage its unity and strength. These findings extend the work by Govinda (2009) that unpacks the trade-offs when NGOs try to mobilise their target groups, and Mullen (2011) which examines the potential of panchayats for citizens and organised groups. 
In Donnapalli panchayat, NGO Akravati has played an important role in building the awareness of sangha members and mobilising them to raise collective demands. It has provided information, strategies, training, technical and logistic support in relation to panchayats. NGO Akravati has also supplemented the efforts of the sangha by liaising with government officials, the MLA and other political leaders at different tiers of government. This has augmented the voice and influence of sangha members as it has helped to step up the pressure on leaders, elected functionaries and officials, both within and outside the panchayat. Given the hierarchical nature of village society, NGO Akravati considers the involvement of its sangha members in electoral activities and confrontational collective action as a necessary step towards the empowerment of poor people:

For us, politics is about securing access to state resources. We are building the capacities of sangha members so that they can do this. The sangha is not vying for power; it is trying to usher in a democratic culture whereby voter interest is supreme... empowerment of the traditionally marginalised has absolutely no meaning without electoral involvement. (NGO head, pers. comm. 2005) $)^{31}$

NGO Akravati has found that over time, with the increasing political competition at the grass roots and the institutionalisation of panchayats, it has had to adapt and strengthen its involvement in panchayat-related activities. However, its awareness-raising and mobilisation measures have brought it into conflict with certain local political leaders and groups whose interests have been threatened. While this has not resulted in any serious setbacks, it has meant that at times field staff (many of whom are sangha members) have had to operate prudently. In addition, the NGO has found that their efforts to build the political capabilities of sangha members have been thwarted by internal village and party politics or by deliberate divisive measures undertaken by those who oppose the sangha. Senior staff are unperturbed as they feel that these tensions and impediments are part of the process of building the capabilities of vulnerable and marginalised people. However, in the longer term, the rise of small-time leaders and associated groups could mean that NGO Akravati finds it difficult to unite different interest groups and sustain sangha mobilisation.
This account of the differing experiences of NGO Akravati builds on existing literature (Rai et al. 2001; Chhotray 2008) that discusses the role that NGOs (largely working in north and central India) can potentially play in mobilising and building the capacities of individuals and groups to participate in panchayats. It does so by providing an insight into the achievements, challenges and limitations faced by an NGO (operating in the south Indian state of Karnataka) that chooses to conscientise and mobilise its target group in relation to panchayats. In doing so, it draws attention to the role and relevance of politics in shaping the experiences of poor people, the functioning of panchayats, and the interventions of NGOs.

In Donnapalli, poor people who are non-sangha members are also recognising the value of engaging in political participation. With the incremental devolution of powers and funds to gram panchayats, and the growing politicisation in village society, they feel that even if they were indifferent or reluctant in the past, they now need to participate in political activities, especially if they want to secure material benefits from panchayats. Some of those who have contacted elected functionaries, submitted petitions or joined protests have found that these different forms of political participation have enabled them to voice their demands more effectively. Others have found that voting collectively as a group has placed them in a better bargaining position, especially in their dealings with traditional elites.

This perception that political participation is becoming necessary has helped the sangha expand membership among poor people in Donnapalli. In turn, this has allowed the poor to have a larger influence over the gram panchayat election results, and hence potentially more say over decision-making and the disbursement of material benefits.

The changing political dynamics over the study period indicate that interactions with traditional elites are increasingly being governed by a culture of negotiation rather than one of patronage. Daftary (2010) finds similar changes occurring in Gujarat and refers to this process of bargaining and compromise as 'brokerage'. Still (2011) has also observed an erosion in the powers of patronage in her research in the south Indian state of Andhra Pradesh. 
Although I concur with Mansuri and Rao (2013) that contextual differences need to be taken into account in order to understand the different ways in which poor people engage with traditional elites and local government institutions, I argue that similar changes in different parts of the country suggest that Donnapalli's experiences in relation to the institutional electoral practices and substantive politics might not be isolated.

This emphasis on context is also echoed in Loera-Gonzalez's study (this IDS Bulletin), on the forms of resistance employed by the Rarámuri people in Mexico. Unlike the sangha members, the Rarámuri have not built ties with external society but have responded to the oppression they face by strengthening their internal cohesion so that they can use their cultural identity as a form of resistance. On the other hand, in a setting like Donnapalli, poor people are using the statutory provisions of local government, combined with the information and support provided by a local NGO to contact, petition and agitate for individual and collective benefits. Those that belong to the sangha are also utilising collective mobilisation, electoral tactics and party politics to secure incremental gains.

Thus, in Donnapalli, the sangha and its members are beginning to both redefine and set the terms on which poor people engage with local government. Although the panchayat president nominated by them is finding it hard to balance different interests and the sangha is facing threats to its unity, the political alliances and strategies of the sangha are making it a force to be reckoned with.

\section{Conclusion}

The longitudinal account of the changing dynamics in Donnapalli gram panchayat has drawn attention to the links between poor people, panchayats, NGOs and politics. It has described how panchayats can be harnessed by vulnerable and marginalised people to usher in political and socioeconomic change at the grass roots. In addition, it has explained how and why it has become increasingly necessary for poor people to engage with politics - not just in terms of institutional electoral practices but also in the more substantive sense of redefining traditional boundaries in order to gain access and influence over decision-making and the distribution of resources and benefits.
The article has highlighted how the constitutional amendment in 1992, the incremental devolution of funds and powers in Karnataka, and the presence of an NGO working on panchayat-related issues have helped to provide an enabling environment in which poor people can engage in substantive political participation. It has shown that in such a context, an active engagement in different forms of institutional electoral practices can help poor people to have a larger influence over the functioning of local government and greater access to material benefits. By discussing the engagement of poor people, NGOs and panchayats in Donnapalli, it provides an insight into the everyday practices and pitfalls of harnessing democratic decentralisation in a context where an organised group has used their collective strength to deepen political participation. In doing so, it has contributed to, and extended the literature on democratic decentralisation, NGOs and politics.

The deepening politicisation in Donnapalli and the devolution of funds is making more poor people consider such an engagement as necessary. However, such an involvement might heighten existing tensions and expand political and social divisions. Further research is required to examine the extent and relevance of these findings in other settings.

Reflecting back on these findings and the process of data collection has reminded me of the everyday struggles faced by many of the poor people I interviewed. Although it has been very encouraging to find that there is greater awareness and willingness to participate in the political process, it remains to be seen whether poor people will be able to build on their strengths and continue to reconfigure existing hierarchies.

Donnapalli's experiences have highlighted how the rise in political competition and the representation of leadership from nontraditional backgrounds has helped to bring about incremental social change. However, the article has also indicated that a proliferation of leaders at the local level offers challenges to the smooth functioning of both the sangha and the panchayat. In doing so, it builds on existing literature by providing fresh insights into the political dynamics at the grass roots in India.

The growing authority of the gram panchayat also draws attention to the need for NGOs to work 
with their target group on panchayat-related issues. The article brings out the importance of the role of NGOs in relation to local government. In particular, it highlights the value of investing efforts in building a collective and nurturing the political capabilities of the group. The NGO can build their awareness about various aspects of panchayats, help them exercise voice, and support them in their endeavours to undertake collective confrontational action and secure an influential role in local government. Poor people, like those in the sangha, can help to make the decisionmaking process within panchayats more

\section{Notes}

1 In 1992, the 73rd constitutional amendment paved the way for the Indian system of threetiered decentralised government within rural parts of an individual state - district (zilla panchayat), sub-district or intermediate (taluk panchayat in Karnataka) and village (gram panchayat). The term Panchayati Raj

Institutions (PRIs) includes all three tiers of panchayats. All references to 'panchayat' refer to the statutory panchayats.

2 Scheduled Castes (SCs) include the former untouchables or outcastes, castes which lie outside the traditional four-fold hierarchy and Scheduled Tribes (STs) (indigenous tribes), are accorded special constitutional status in view of the discrimination they have suffered in the past from mainstream Hindu society.

3 NGOs (non-governmental organisations) are defined here as 'self-governing, private, notfor-profit organisations that are geared to improving the quality of life of disadvantaged people' (Vakil 1997: 2060). This definition places emphasis on the 'developmental' role of NGOs and excludes organisations such as 'business, professional, recreational, cultural and strictly religious organisations that are usually considered as part of the non-profit sector' (ibid.).

4 I define these as NGOs that operate in a specific geographical arena, namely, the sub-district administrative division.

5 This characterisation draws on Manor's description of politics as 'the interplay of interests and forces in pursuit of power, resources, status etc.' (2004: 205).

6 The traditional four-fold hierarchy consists of four varnas (categories): Brahmin (priest), Kshatriya (warrior), Vaishya (merchant) and Shudras (peasant, service and artisan castes). transparent, and the developmental outcomes more equitable, but even they are susceptible to political machinations and subject to internal divisions.

Despite these challenges, Donnapalli's account shows us that both poor people and NGOs can benefit from a greater involvement with panchayats. Furthermore, with the deepening politicisation at the grass roots and the progressively higher devolution of resources, it has become increasingly necessary for poor people to engage in different aspects of political participation.

'Upper castes' normally refers to castes belonging to the first three varnas.

7 Following Srinivas, 'dominant' is understood to refer to castes that control a substantial portion of landholdings associated with the village, have a sizeable (does not imply majority) numerical strength within the village that translates into socioeconomic standing and control over political patronage, possess the hereditary headman's post, and enjoy a relatively 'high' status within the traditional caste hierarchy (1959).

8 The period covers two full five-year electoral terms of gram panchayats and one year of the third electoral term.

9 When selecting poor respondents for survey interviews I followed a three-stage strategy. Firstly, I collected information about a potential list of interviewees in a general group discussion. I then triangulated this information with key informants from both the well-off and poor categories. Finally, I did a round of the village and gauged their situation for myself. This information in tandem with research criteria helped me draw up the final list of respondents. I administered surveys to both sangha and non-sangha members (men and women). The majority of the respondents were from the Scheduled Caste community and were daily-wage labourers.

10 Telugu is the language associated with the state of Andhra Pradesh and Kannada is the language associated with Karnataka. However, the people in this legislative constituency within Karnataka largely speak Telugu as the area borders the state of Andhra Pradesh.

11 Interview with panchayat secretary No. 14, 2 September 2006, Kolar. 
12 This district was part of Kolar district during the study. In 2007, Kolar was bifurcated and this panchayat became part of Chikballapur district.

13 Names of NGO, legislative constituency, gram panchayat, and key people in this area have been altered.

14 This is often shortened to CPM.

15 An influential caste grouping belonging to the Shudra varna.

16 He stood as an independent during elections as he was not selected as the official candidate by the Congress party. However, he continues to be affiliated to the Congress.

17 Interviews with MLA, NGO Akravati staff and functionaries of sangha, Kolar, 2006.

18 Elections for all three tiers of panchayats were held in 1994-5, 2000 and 2005. The pattern of CPM dominance in the upper tiers was only broken in the 2005 term, when a zilla panchayat member from the Congress party got elected.

19 The Karnataka Panchayati Raj Act provides reservations for marginalised communities (women, religious minorities, SC/STs and backward castes) both for the post of ward member and GP president.

20 Since 2000, gram panchayat terms in Karnataka have been split into two equal halves.

Reservations for the post of panchayat president are 'rotated' mid-way through the term allowing for two presidential tenures of 30 months each.

21 Karnataka has a system of indirect elections for the gram panchayat president. Ward

\section{References}

Alm, B. (2010) 'Creating Followers, Gaining Patrons: Leadership Strategies in a Tamil Nadu Village', in P. Price and A.E. Ruud (eds), Power and Influence in India: Bosses, Lords and Captains, New Delhi: Routledge

Alsop, R.J.; Krishna, A. and Sjoblom, D. (2001) Inclusion and Local Elected Governments: The Panchayat Raj System in India, Washington DC: World Bank South Asia Unit

Bardhan, P.; Mitra, S.; Mookherjee, D. and Sarkar, A. (2009) 'Local Democracy and Clientelism: Implications for Political Stability in Rural West Bengal', Economic and Political Weekly 44.9: 46-58

Bhatt, V.N. (2012) Here I Am, There I Go, www.tehelka.com (accessed 20 April 2013)

Booth, D.; Leach, M. and Tierney, A. (2006) Experiencing Poverty in Africa: Perspectives from Anthropology, Q-Squared Working Paper 25, Toronto: Q-Squared, Centre for International Studies (council) members elect an appropriate candidate from amongst themselves, based on the reservation 'category'. In practice, heavy contestation means that the largest number of like-minded ward members (invariably same political-party affiliation) has the final say in making this decision.

22 Interview with elected male member No. 39, 31 August 2006, Kolar.

23 Technically, he belongs to the same caste grouping as the landowning family but he comes from a lower class.

24 Interview with elected male member No. 38, 31 August 2006, Kolar.

25 Interview with sangha functionary No. 5, 26 August 2006, Kolar.

26 Interview with knowledgeable informant No. 48, 28 August 2006, Kolar.

27 Interview with NGO head, 12 October 2005, Kolar.

28 Interview with key informant from the dominant caste, 30 August 2006, Kolar.

29 The gram panchayats now receive a sizeable proportion of the funds under the Mahatma Gandhi National Rural Employment Guarantee Act (MGNREGA) of 2005.

30 Interview with sangha functionary No. 5, 26 August 2006, Kolar.

31 Interview with NGO head, 12 October 2005, Kolar.

Chandrashekhar, L. (2009) 'Caste, Party and Democratic Decentralisation in Karnataka', in B.S. Baviskar and G. Mathew (eds), Inclusion and Exclusion in Local Governance: Field Studies from Rural India, Los Angeles: Sage

Chhotray, V. (2008) 'Political Entrepreneurs or Development Agents? An NGO's Story of Resistance and Acquiescence', in A. Bebbington, S. Hickey and D. Mitlin (eds), Can NGOs Make a Difference? The Challenge of Development Alternatives, London: Zed

Cornwall, A.; Robins, S. and Von Lieres, B. (2011) States of Citizenship: Contexts and Cultures of Public Engagement and Citizen Action, IDS Working Paper 363, Brighton: IDS

Daftary, D. (2010) 'Elected Leaders, Community and Development: Evidence on Democratic Decentralization and Distributional Outcomes from a Case in India', Journal of Development Studies 46.10: 1692-707 
DFID (2010) The Politics of Poverty: Elites, Citizens and States, London: Department for International Development

Dutta, S. (2012) 'Power, Patronage and Politics: A Study of Two Panchayat Elections in the North Indian State of Uttar Pradesh', South Asia: Journal of South Asian Studies 35.2: 329-52

Govinda, R. (2009) 'In the Name of "Poor and Marginalised"? Politics of NGO Activism with Dalit Women in Rural North India', Journal of South Asian Development 4.1: 45-64

Green, D. (2008) From Poverty to Power: How Active Citizens and Effective States can Change the World, Oxford: Oxfam International

Hansen, S.D. (1999) 'NGO's Role in Increasing People's Participation in Local Decentralised Government', in D. Rajasekhar (ed.), Decentralised Government and NGOs: Issues, Strategies and Ways Forward, New Delhi: Concept

Harriss, J.; Stokke, K. and Törnquist, O. (eds) (2004) 'Introduction: The New Local Politics of Democratisation', in J. Harriss, K. Stokke and O. Törnquist (eds), Politicising Democracy: The New Local Politics of Democratisation, Basingstoke and New York: Palgrave

Krishna, A. (2007) 'Politics in the Middle: Mediating Relationships between the Citizens and the State in Rural North India', in H. Kitschelt and S. Wilkinson, S. (eds), Patrons, Clients and Policies: Patterns of Democratic Accountability and Political Competition, Cambridge: Cambridge University Press

Kudva, N. (2006) 'Shaping Democracy through Organisational Practice: The NGOs of the Tribal Joint Action Committee in Karnataka, India', International Journal of Rural Management 2.2: 227-43

Mandlebaum, D.G. (1970) Society in India: Change and Continuity, Berkeley CA: University of California Press

Manor, J. (2010) 'What do they Know of India Who Only India Know? The Uses of Comparative Politics', Commonwealth and Comparative Politics 48.4: 505-16

Manor, J. (2004) 'User Committees: A Potentially Damaging Second Wave of Decentralisation?', European Journal of Development Research 16.1: 192-213
Mansuri, G. and Rao, V. (2013) 'Can Participation be Induced? Some Evidence from Developing Countries', Critical Review of International Social and Political Philosophy 16.2: 284-304

Mathew, G. and Buch, N. (eds) (2000) Status of Panchayati Raj in the States and Union Territories of India 2000, New Delhi: Institute of Social Sciences

Meenakshisundaram, S.S. (2005) 'Rural Development for Panchayati Raj', in L.C. Jain (ed.), Decentralisation and Local Governance, New Delhi: Orient Longman

Mullen, R. (2011) Decentralisation, Local Governance and Social Well Being in India: Do Local Governments Matter?, New York: Routledge

Palaniswamy, N. and Krishnan, N. (2012) 'Local Politics, Political Institutions, and Public Resource Allocation', Economic Development and Cultural Change 60.3: 449-73

Priyadarshee, A. and Hossain, F. (2010) 'Decentralisation, Service Delivery, and People's Perspectives: Empirical Observations on Selected Social Protection Programs in India', International Journal of Public Administration 33.12: 752-66

Rai, M.; Nambiar, M.; Paul, S.; Singh, U.S. and Sahni, S.S. (eds) (2001) The State of Panchayats: A Participatory Perspective, New Delhi: Samskriti

Robinson, M.S. (1988) Local Politics: The Law of the Fishes: Development through Political Change in Medak District, Andhra Pradesh (South India), Delhi: Oxford University Press

Sharma, D. and Sudarshan, R.M. (2010) 'Towards a Politics of Collective Empowerment: Learning from Hill Women in Rural Uttarakhand, India', IDS Bulletin 41.5: 43-51

Srinivas, M.N. (1959) 'The Dominant Caste in Rampura', American Anthropologist 61.1: 1-16 Still, C. (2011) 'The State in the Palli: Dalit Perspectives on the State in Andhra Pradesh', Contemporary South Asia 19.3: 315-29

Vakil, A.C. (1997) 'Confronting the Classification Problem: Toward a Taxonomy of NGOs', World Development 25.12: 2057-70 